\title{
Petanque: Mental Imagery and Shooting Accuracy
}

\author{
$1^{\text {st }}$ Rony M R \\ Physical Education, Health and \\ Recreation Study Programs \\ STKIP PASUNDAN \\ Cimahi, Indonesia \\ denrony@gmail.com
}

\author{
$2^{\text {nd }} M$ Asmawi \\ Faculty of Post Graduate Sports \\ Education, State \\ University of Jakarta \\ Jakarta, Indonesia \\ asmawi.moch1@gmail.com
}

\author{
$3^{\text {rd }}$ Johansyah Lubis \\ Faculty of Sports Science, State \\ University of Jakarta \\ Jakarta, Indonesia \\ johansyah888@yahoo.co.id
}

\begin{abstract}
Research aims to look at the effect of mental imagery on the accuracy of shooting at sport petanque. The research method used is pre-test - post-test one group, with the precision shooting test instrument from FIPJP. The population of this study were all petanque associations in the Greater Bandung area with a total of 5 petanque associations, the sampling technique used was cluster random sampling so that the sample in this study obtained one petanque association. who came from the Cimahi region with a total of 20 athletes. According to analysis by SPSS 20 using analysis of paired samples t-test, the obtained scores $t$ hit by 10,50 by level significance of $0.00<0,05$, so that it can be concluded that mental imagery exercise influence on the accuracy of shooting at petanque sports.
\end{abstract}

\section{Keywords-Mental Imagery, Accuracy, Petanque.}

\section{INTRODUCTION}

Petanque is a sport that entered Indonesia in 2011. This sport is one of the sports that are competed in multi-events such as the West Java National Sports Week (PON) in 2016 [1]. The sport of pentaque itself is a sport that has quite unique game characteristics, where in this game each player throws an iron ball to approach a wooden ball and tries to keep the opponent's iron ball away from the wooden ball [2], besides that the sport is capable of compete to produce achievements from each number competed [3]. In this sport, there are many numbers contested including single man and woman, double man and woman, triple man and woman, triple mix and precision shooting numbers [4] and have two throwing techniques, namely shooting and pointing [5]. For precision shooting numbers basically have provisions or rules in the game, such as throws with a distance of six meters, seven meters, eight meters, nine meters with the acquisition of points starting from one, three, five points for each throw that is taken [6]. The most important thing in this sport, especially for precision shooting numbers, is accuracy [7] [8]. One way to improve shooting accuracy is by providing training in the form of imagery training [9].

The mental imagery exercise carried out by athletes basically aims to increase the athlete's confidence which will have an impact on increasing their motor skills so that it will indirectly have an impact on athlete's performance [10]. Even imagery training is a form of practice that can help improve shooting accuracy [11] [12] [13]. This exercise helps athletes to imagine the recording process either from motion experiences or in the form of images and or videos and then applied in a form of motion skills [14]. Imagery training has been applied more to several sports that have team characteristics such as football [15], shooting [16], basketball [17], volleyball [18] while individual sports are limited to the application of sports [16], gymnastics [19] and yet for the petanque sport, not many have studied the application of mental imagery, especially in the Greater Bandung area. Therefore, the purpose of this study focuses more on seeing the effect of the application of mental imagery on the accuracy of shooting petanque in the Greater Bandung area.

\section{RESEARCH METODS}

The purpose of this study is to focus more on finding out the effect of the application of mental imagery on shooting accuracy in the Petanque sport. Looking at the objectives to be achieved in this study, the research method chosen for use is by using the experimental research method with the pre-test-posttest one group design, where the variable that becomes the treatment in this study is mental imagery training which is also an independent variable. while the dependent variable is shooting accuracy. The research instrument used was a precision shooting test from FIPJP (Fédération Internationale de Pétanque et Jeu Provençal). The population in this study were all petanque associations in the Bandung Raya area as many as 5 cities / regencies and for sampling using a sampling technique in the form of cluster random sampling, so the number of samples in this study was the Petanque association in the Cimahi area with 20 athletes. athlete. The data analysis used was paired simple t-test analysis.

\section{RESEARCH RESULTS AND DISCUSSION}

\section{A. Research Result}

\begin{tabular}{|rr|r|r|r|r|}
\hline & Mean & \multicolumn{1}{c|}{$\mathrm{N}$} & \multicolumn{1}{c|}{$\begin{array}{c}\text { Std. } \\
\text { Deviation }\end{array}$} & \multicolumn{1}{c|}{$\begin{array}{c}\text { Std. Error } \\
\text { Mean }\end{array}$} \\
\hline & & & 20 & 8.249 & 1.845 \\
Pair 1 & Posttest & 23.55 & 20 & 8.074 & 1.805 \\
& Pretest & 18.35 & 20 &
\end{tabular}

Table 1 shows that the mean value in the initial test process was 23.55 with a standard deviation value of 8.25 ; while the average value in the final test process was 18.35 with a standard deviation score of 8.07. 
Research Data Prerequisite Test

Table 2. Research Data Normality Test Using the One-Sample Kolmogorov-Smirnov Test

\begin{tabular}{|cc|r|r|}
\hline \multicolumn{2}{|c|}{ Kolmogorov-Smirnov Test } \\
\hline N & \multicolumn{1}{|c|}{ Pretest } & \multicolumn{1}{c|}{ Posttest } \\
\hline \multirow{2}{*}{ Normal Parameters ${ }^{\mathrm{a}, \mathrm{b}}$} & Mean & 20 & 20 \\
& Std. & 8.074 & 23.55 \\
& Deviation & & 8.249 \\
Most Extreme Differences & Absolute & .217 & .271 \\
& Positive & .217 & .271 \\
& Negative & -.128 & -.100 \\
& .972 & 1.214 \\
Kolmogorov-Smirnov Z & $\mathbf{. 3 0 2}$ & $\mathbf{. 1 0 5}$ \\
\hline
\end{tabular}

a. Test distribution is Normal.

b. Calculated from data.

Table 2 shows the scores for the results of the analysis of the normality test using the One-Sample Kolmogorov-Smirnov Test analysis. Table 2 shows that the Asymp.Sig 2-tailde score / value shows a score of 0.302 for the pre test score and 0.105 for the post test score. The significance value shows the number is greater than 0.05 (significance> 0.05), which means that the overall data is normally distributed.

Table 3. Shooting Results Homogeneity Test

Test of Homogeneity of Variances

\begin{tabular}{|c|c|c|c|}
\hline \multicolumn{4}{|c|}{ Boot_Range } \\
\hline Levene Statistic & df1 & $\mathrm{df} 2$ & Sig. \\
\hline .062 & 1 & 38 & .805 \\
\hline
\end{tabular}

Table 3 shows the results of the analysis of hypothesis testing using the analysis of the test of Homogeneity of Variances. The homogeneity test results showed a score of 0.62 with a significance level of $0.805>0.05$, meaning that the overall research data had the same variance (homogeneous).

Table 4. The Influence of Mental Imagery on the Accuracy of Petanque Shooting

Paired Samples Test

\begin{tabular}{|c|c|c|c|c|c|c|c|c|}
\hline & \multicolumn{5}{|c|}{ Paired Differences } & \multirow[t]{3}{*}{$\mathrm{t}$} & \multirow[t]{3}{*}{$\mathrm{df}$} & \multirow{3}{*}{$\begin{array}{l}\text { Sig. } \\
(2- \\
\text { tailed } \\
\quad)\end{array}$} \\
\hline & \multirow[t]{2}{*}{ Mean } & \multirow[t]{2}{*}{$\begin{array}{c}\text { Std. } \\
\text { Deviat } \\
\text { ion }\end{array}$} & \multirow[t]{2}{*}{$\begin{array}{c}\text { Std. } \\
\text { Error } \\
\text { Mean }\end{array}$} & \multicolumn{2}{|c|}{$\begin{array}{c}95 \% \\
\text { Confidence } \\
\text { Interval of the } \\
\text { Difference } \\
\end{array}$} & & & \\
\hline & & & & Lower & Upper & & & \\
\hline $\begin{array}{l}\text { Posttest - } \\
\text { Pretest }\end{array}$ & 5.200 & 2.215 & .495 & 4.163 & 6.237 & $\begin{array}{r}10.5 \\
00\end{array}$ & 19 & .000 \\
\hline
\end{tabular}

Table 4 shows the results of t-test calculations using paired simple t-test analysis. Based on the results of the calculation in the analysis, the $t$ test results obtained were 10,500 with a significance level of $0,000<0.05$ (significant), meaning that the shooting accuracy results in petanque sports can be improved through the application of mental training imagery.

\section{B. DISCUSSION}

The results of research on the effect of mental imagery on shooting accuracy in petanque sports show that mental training imagery intervention for athletes can increase the level of shooting accuracy. This happens because the exercises given imagery, atlet increase the ability of motor [20], the muscle strength of his [21] and make the joints more flexible [22]. As previously discussed, the precision shooting petanque number requires athletes to shoot from a distance of $6,7,8$ and 9 meters with 5 types of obstacle variations [23], so that good motor skills, joint flexibility and management of muscle strength are needed.

The imagery training intervention carried out in this study was to assign athletes to analyze the previously recorded video shooting themselves, so that they would be stored in the brain's memory [24] shooting movements that should have been carried out within a specified distance. Then the athlete is given the task to imagine the shooting movement that is carried out, which is then practiced without using the ball, which is used to strengthen the imagination, because a strong imagination leads to the creation of nerve impulses similar to those produced when doing the actual movement [24]. After the athlete is sure that his or her image is doing well, then the ball is given to then do the actual shoo ting with several variations of the obstacle and shooting distance. Imagery intervention treatment was carried out for 8 weeks, 3 days in one week, with 30 minutes of imagery training and 60 minutes of shooting practice. This is done because all athletes have never had a mental training program before. So that a training program of 24 sessions is sufficient to get the desired results [25].

Several studies have confirmed that imagery training can improve athlete performance, reduce anxiety, increase concentration and self-confidence [26] [27][28]. These four things are really needed by an athlete, especially in the precision shooting number which requires a high level of concentration and self-confidence when aiming and shooting. Moreover, the conditions on the field, when entering the quarter-finals to the finals, which require athletes to compete directly with their opponents in obtaining scores, good imagery skills are needed so that athletes are not distracted by their concentration by the scores of their opponents. Imagery is the most commonly used technique to improve athlete performance in competitive situations [24].

The results of this study indicate that imagery as a fundamental cognitive process to produce motor movements and performance enhancement is suitable for use by no mor precision shooting petanque athletes in an effort to improve shooting accuracy. This is reinforced by the large number of world elite athletes (70-90\%) who state that they use imagery to improve performance [29]. Although for elite athletes the precision sho oting petanque number has not been detected using imagery, professional athletes of basketball, soccer, gymnastics, volleyball, dance, and swimming, have often done imagery motor training [30]. Therefore, it is advisable for Petanque trainers to apply mental imagery training in improving the shooting accuracy of athletes, especially in precision shooting numbers. 


\section{CONCLUSION}

Judging from the results of data processing and analysis in this study, it can be concluded that there is an effect of mental imagery on the results of shooting accuracy in petanque sports.

\section{REFERENCES}

[1] A. T. Agustina and A. Priambodo, "Hubungan Antara Tingkat Konsentrasi Terhadap Hasil Ketepatan Shooting Olahraga Petanque Pada Peserta Unesa Petanque Club," Pendidik. Olahraga dan Kesehat., vol. 5, no. 3, pp. 391-395, 2017.

[2] CMSB, "Petanque (online)," 2015.

[3] F. A. Irawan, D. F. W. Permana, H. R. Akromawati, and H. Yang-tian, "Biomechanical Analysis of Concentration and Coordination on The Accuracy in Petanque Shooting," J. Phys. Educ. Sport. Heal. Recreat., vol. 8, no. 2, pp. 96-100, 2019.

[4] W. Widodo and A. Hafidz, "Kontribusi Panjang Lengan, Koordinasi Mata Tangan, dan Konsentrasi Terhadap Ketepatan Shooting Pada Olahraga Petanque," Prestasi Olahraga, vol. 3, no. 1, pp. 1-6, 2018

[5] R. Eko Cahyono, "Analisis Backswing Dan Release Shooting Carreau Jarak 7 Meter Olahraga Petanque Pada Atlet Jawa Timur,” J. Prestasi Olahraga, vol. 1, no. 1, pp. 1-5, 2018.

[6] T. F. I. de. Petanque, "THE OFFICIAL INTER-NATIONAL RULES OF THE GAME OF PETANQUE," 2002

[7] Seouf, "The Winning Trajectory," Malaysia: Copy Media, 2015.

[8] Y. N. Hanief and A. M. I. Purnomo, "Petanque: What are the physical factors that determine performance ?," vol. 7, no. 2, pp. 116-125, 2019.

[9] M. R. Lubis and A. G. Permadi, "Perbedaan Pengaruh Latihan Imagery Dan Tanpa Latihan Imagery Terhadap Peningkatan Kemampuan Shooting Game Atlet Petanque Undikma," J. Ilm. Mandala Educ., vol. 6 , no. 1, pp. 101-106, 2020.

[10] A. Filgueiras, "Imagery for the Improvement of Serving in Beach Volleyball: A Single Case Study," Rev. Bras. Psicol. do Esporte, vol. 6, no. 3 , pp. $57-76,2017$

[11] W. Rama Alestio, "Pengaruh Circuit Training Dan Imagery Terhadap Akurasi Tendangan Penalti Sepakbola,” J. Patriot, pp. 263-269, 2018.

[12] A. Candra, "Pengaruh Latihan Menendang Menggunakan Imageri Terhadap Akurasi Tendangan Ke Gawang," J. Sport Area, vol. 1, no. 1, p. 1, 2016.

[13] R. T. Nurfalah, S. Ugelta, and I. Imanudin, "Pengaruh Imajery Training terhadap Keterampilan Hasil Shooting Sepak Bola di SSB Java Putra Yudha," J. Terap. Ilmu Keolahragaan, vol. 1, no. 1, p. 40, 2016.

[14] G. G. SM Kosslyn, WL Thompson, "The case for mental imagery," books.google.com, 2006.

[15] A. Sufriyanto and Y. Y. Putra, "Pengaruh Latihan Imagery Mental Terhadap Kepercayaan Diri Atlet Sepakbola Kabupaten Kerinci,” Univ.
Negeri Padang, vol. 0, pp. 1-12, 2019.

[16] S. A. P. Wibowo and N. I. Rahayu, "Pengaruh Latihan Mental Imagery Terhadap Hasil Tembakan Atlet Menembak Rifle Jawa Barat," J. Terap. Ilmu Keolahragaan, vol. 1, no. 2, p. 23, 2016.

[17] A. Fuad and Sudarso, "Pengaruh Mental Imagery Terhadap Hasi Belajar Bola Basket Teknik Dasar Lay Up Dalam Pembelajaran Penjasorkes," J. Pendidik. Olahraga dan Kesehat., vol. 02, no. 03, pp. 722-727, 2014.

[18] A. Septiyanto and S. Suharjana, "Pengaruh Metode Latihan Imagery Dan Konsentrasi Terhadap Ketepatan Floating Service Atlet Bola Voli Diy," J. Cakrawala Pendidik., vol. 35, no. 3, pp. 412-420, 2016.

[19] H. Firmansyah, "Perbedaan Pengaruh Latihan Imagery Dan Tanpa Latihan Imagery Terhadap Keterampilan Senam Dan Kepercayaan Dir Atlet," J. Olahraga Prestasi, vol. 7, no. 7, pp. 1-10, 2011.

[20] D. L. Feltz and D. M. Landers, "The Effects of Mental Practice on Motor Skill Learning and Performance: A Meta-analysis," J. Sport Psychol., vol. 5, no. 1, pp. 25-57, 2016.

[21] G. Yue and K. J. Cole, "Strength increases from the motor program: Comparison of training with maximal voluntary and imagined muscle contractions," J. Neurophysiol., vol. 67, no. 5, pp. 1114-1123, 1992

[22] A. Guillot, C. Tolleron, and C. Collet, "Does motor imagery enhance stretching and flexibility?," J. Sports Sci., vol. 28, no. 3, pp. 291-298, 2010 .

[23] Nurhasan, Olahraga Petanque, 1st ed. Surabaya: Unesa University Press, 2020.

[24] V. Parnabas, "The influence of mental imagery techniques on sport performance among Taekwondo athletes," Eur. Acad. Res., vol. II, no. 11, pp. 14729-14734, 2015.

[25] J. S. Shaari, L. B. Hooi, and S. Siswantoyo, "The Effectiveness of Psychological Skills Training Program on Netball Shooting Performance," J. Cakrawala Pendidik., vol. 38, no. 1, pp. 174-187, 2019.

[26] R. H. Cox, Sport Psychology Concepts and Applications, 7th ed., vol. 14, no. 2. New York: McGraw-Hill, 2016.

[27] A. Doussoulin and L. Rehbein, "Motor Imagery as a Tool for Motor Skill Training in Children," Motricidade, vol. 7, no. 3, pp. 37-43, 2011.

[28] S. H. Mousavi and A. Meshkini, "The Effect of Mental Imagery upon the Reduction of Athletes Anxiety during Sport Performance," Psychol. Sport Exerc., vol. 20, no. February 2015, pp. 623-35, 2011.

[29] N. Mizuguchi, H. Nakata, Y. Uchida, and K. Kanosue, "Motor Imagery and Sport Performance," J. Phys. Fit. Sport. Med., vol. 1, no. 1, pp. 103-111, 2012

[30] J. Cumming and C. Hall, "Deliberate Imagery Practice: The Development of Imagery Skills in Competitive Athletes," J. Sports Sci. vol. 20 , no. 2 , pp. $137-145,2002$. 